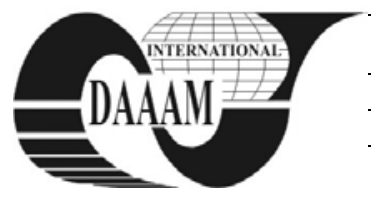

Annals of DAAAM for 2011 \& Proceedings of the 22nd International DAAAM Symposium, Volume 22, No. 1, ISSN 1726-9679 ISBN 978-3-901509-83-4, Editor B. Katalinic, Published by DAAAM International, Vienna, Austria, EU, 2011 Make Harmony between Technology and Nature, and Your Mind will Fly Free as a Bird Annals \& Proceedings of DAAAM International 2011

\title{
JUST IN TIME CONCEPT AS A MEAN FOR ACHIEVING COMPETITIVE ADVANTAGE IN THE VIRTUAL ECONOMY
}

\author{
MORIC MILOVANOVIC, B[ojan]; SISEK, B[oris] \& KOLAKOVIC, M[arko]
}

\begin{abstract}
In today's global economy virtual enterprises are structured as a network of independent companies and are linked by information technologies in order to achieve various competitive advantages. One form of such an cooperative agreement is just in time system of production where a company adopts an inventory strategy that strives to improve a business's return on investment by reducing in process inventory and associated carrying costs. Therefore, the purpose of this paper is to explain the importance of just in time system on an example of one company operating in virtual economy. Key words: virtual economy, just in time system, Croatia
\end{abstract}

\section{INTRODUCTION}

In today's economy characterized by the global economic crisis which has shaken most of the countries in the world and most of the industries, the only sure recipe for business success is focusing on the creativity, innovation and the use of modern technologies. These new turbulent times and the modern global marketplace seek new ways of organizing that will contribute to achieving the competitive advantage, flexibility, innovation and continuous operational improvements. Technological improvements, information and communication capabilities, increase in the amount of information and general knowledge have created the possibility of transforming the traditional, socalled industrial economy into a new, virtual economy (Kolakovic, 2000).

Although the virtual business in its various forms has been used in practice for many years, the concept of virtual business has particularly gained momentum in today's business world. Already known concepts, such as BPR - business process reengineering, JIT - just in time, LM - lean manufacturing, TQM - Total Quality Management, etc, are united in a new way in order to adapt to new business and market opportunities. The virtual organization model represents a new way of looking at the already known methods of collaboration and cooperation which have assumed new dimensions and intensities that exceed the traditional organizational frameworks.

\section{JUST IN TIME CONCEPT}

Just in time (JIT) is a worldwide accepted specific form of production and inventory management developed in. It is based on the concept of production without stock and warehouses. Suppliers deliver required production components just before the assembly operation begins. JIT management requires excellent planning and organization of work, clearly defined contractual obligations and strict delivery deadlines. These or similar methods are also called zero-inventory, production without inventory, and stock control management.

Just in Time is an economic term for the strategy to reduce production costs. The need for large storage cost of intermediate goods is lost and the raw materials are exploited in the shortest possible during the production process (Kelly \& Turban, 2009). The aim for the introduction of Just-in-time system is to reduce inventories, improve supply quality control, reduce administration and processing of documents associated with the delivery and shipping, increase the delivery speed and accuracy in order to avoid delays and losses in the next step of the production chain (Samanovic, 2009). Everything is in the rapid flow and quality control. Focus is put on the entire system which is composed of several factors. Cost reductions refer to storage, complaints, paperwork and the amount of errors in the production process. The system is monitored from the inside and each employee has the right to express complaints on the manufacturing process and draw attention to errors.

Production system in which each process produces accurate enough output to take to the next process in continuous sequence. Just-in-time production management concept focuses on improving the supply chain with the ultimate goal of eliminating inventory, product storage and intermediate storage parts in the production chain. It is a production management system that requires a high degree of control over the production process, maximum compliance with the activities regarding production process and total quality control of products (Kolakovic \& Tipuric, 2002). Just in time supply system is oriented to the user needs, and is used for materials and products with a large proportion in the consumption, for which it pays off to synchronize the production in the value chain according to daily programs. In the JIT system it is necessary to have a backup supply source and a supplier with whom we make up the JIT system must have ISO quality certificate (Zirbet, 2007).

\section{ADVANTAGES OF JUST IN TIME CONCEPT IN THE VIRTUAL ECONOMY}

Advantages of the Just-in-time concept allow manufacturing system a fast and efficient production of high quality products that fully meet customer needs. By producing products only when needed and with a strong quality control, manufacturing system prevents the creation of waste and thus reduces the amount of energy, raw materials and other used resources, which presents an important management tool in building ecologically sustainable business.

For the customers this means a top quality product with many features, which can be delivered faster and with a significantly less cost. The introduction of such a system in the production allows a creation of detailed production plans with the aim to eliminate all unnecessary delays (Kolakovic \& Tipuric, 2002). Company must meet the following conditions if ti wants to effectively apply Just-in-time system:

(1) Ensure delivery of products without error because defective products require high replacement costs.

(2) Synchronize the capacities in the entire production chain in order to eliminate unnecessary stockpiling.

(3) Establish independent but cooperative work teams and groups across all departments so they could deliver faster and better solutions to the specific problems. 
(4) Focus production on specialized products or service which are produced in small batches in order to gain the ability for easy adjustment to market changes.

(5) Ensure the optimum procurement flow of materials, preferably, from a small number of suppliers, which reduces the logistic costs and increases the security of supply.

If the above mentioned requirements were successfully fulfilled the company can expect a maximum benefits from the introduction of Just In Time system, especially in the reduction of working capital and in the faster capital turnover (Kolakovic \& Tipuric, 2002). Just in time the method is successful only when the quality of the parts is high and when there are no large inventories and warehousing. In addition, strong cooperation with the suppliers need to be in the vicinity of the company, teamwork, production size in line with demand, etc. The overall result is a satisfied customer.

\section{JUST IN TIME SYSTEM - THE CASE OF PEVEC D.O.O.}

In today's global financial crisis, in order to survive, companies are forced to rationally use all its resources, and minimize their operating costs. In Croatia, the application of JIT information systems is still in its infancy, and the disintegration of one of the largest shopping centers in Croatia will be described in brief. Bankruptcy of the retail company Pevec d.o.o. occurred for several reasons, but the main reasons are closely associated with just-in-time system and its main determinants. Pevec d.o.o. as a large company with several hundred employees, has not had a good staff of high quality people in an information system that took care of the stocks in shopping malls, and supplies in general. The stocks of goods and procurement were not in accordance with customer orders, and therefore the goods piled up in warehouses and shopping malls without finding their customers.

Pevec d.o.o. did not have professional marketing team to research the market and did not know customers' needs and their desires for certain products. Trimmers were the ones who were in charge for the supply and delivery of goods to end customers, and this way of doing business in this age of modern technology and the increasing growth of the virtual economy in Croatia and Europe was not sustainable, and it was only a matter of time before this old-fashioned system would break down. Also, uneconomical procurement of 300 new trucks, an investment that certainly was not required, was paid off by leasing. They went out to European cities in one direction filled with goods, and when coming back were empty. This case best describes such a business as irrational, and not only did it not reduced costs, but in fact it has drastically increased them. Pevec d.o.o. did not outsourced any company which would deal with paperwork and accounting issues which could be able to point out the enormous endyear loses to the management. Top management simply was not aware where have all the money gone.

All this probably would not have happened if the top management has realized on time that it is necessary to restructure the company and to employ new staff in marketing, purchasing, delivery, and information system departments. Change in company's strategy was the crucial thing which was not made on time and it lead to the sharp increase in overall costs. Bankruptcy of Pevec d.o.o. probably would not have happened if the company has implemented an information system based on Just-in-time concept, which would reduce the number of employees and simultaneously reduce inventories in warehouses. It would also allow timely delivery of goods to customers and timely purchasing of goods from abroad in so that the aforementioned trucks would not go empty on their way back. Therefore, the key reason for the collapse of Pevec d.o.o. is the usage of outdated business technology. Moreover, it can be said that any other similar company with the outdated technology is condemned to fail, just like Pevec d.o.o.

\section{CONCLUSION}

Just-in-time production system is one of the most developed systems that seek to improve business operations and remove all deficiencies in the company. JIT system aims to improve operations so as to minimize inventory and thus eliminate inventory costs that would otherwise constitute the most significant costs for the company. JIT is actually a business philosophy where people (employees) have to function perfectly in order for the system to function. Therefore, management must involve employees in decision making, and allow employees to control the entire production system, discover errors and correct them. In order for JIT system to function, the whole chain from the supplier until the buyer has to be perfectly integrated. The supplier must deliver materials on time and the material has to be perfect quality. This requires long-term cooperation (long-term contracts between companies and suppliers), and there must be high level of trust between the company and its suppliers.

Implementation of the JIT system is a major expense for the company due to the required implementation of business process reengineering in the company, but it brings many advantages and benefits for the company, as well. Some of the advantages are labor cost reduction, transport cost reduction, greater employee motivation, reduced time for production, high quality products, no manipulation of the stock in the warehouse (the minimum inventory), etc. In addition to the benefits, JIT has disadvantages, such as dependency on the suppliers, greater error consequences in the production process, etc. Unfortunately Croatian companies are not ready yet to fully implement the JIT system mostly because it represents a major expense to them, and they would need to completely reconstruct their business processes. For such a great transformation most of Croatian companies are not ready yet.

\section{REFERENCES}

Cunha, M.M., Putnik, G.D., Avila, P.S. (2006) Agile Vitrual Entreprise. Implementation and Management Support, IDEA Group Publishing, ISBN: 1-59904-010-7

Kelly, R. K., Jr., Turban, E. (2009) Introduction to Information Systems: Supporting and Transforming Business, John Wiley and Sons, New York, ISBN: 978-0470169001

Kolakovic, M. (2003) VAVE - A Model for Measuring the Business Performance of Virtual Enterprise, in Putnik, G.D., Gunasekaran, A. Business Excellence $I$ Performance Measures, Benchmarking and Best Practices in New Economy, University of Minho, Braga, Portugal, ISBN: 972-8692-08-0

Kolakovic, M. (2010) Virtualna ekonomija - kako poslovati u uvjetima krize, Strategija d.o.o., Zagreb, ISBN: 798-95356260-0-8

Kolakovic, M., Tipuric, D. (2002) Competitiveness of the Small and Medium Enterprises in Croatia - Strategic Alliances and Virtual Organization Challenges, Asian Small Business Review, ISSN: 1598-5266,Vol. 4, No. 1, pp. 1-20

Samanovic, J. (2009): Prodaja, distribucija, logistika: teorija $i$ praksa, Ekonomski fakultet Split, Split; ISBN: 978-953281-012-7

Zibert, B., (2007) Strateška nabava, MATE, Zagreb 